Article

\title{
Early Regeneration Dynamics of Pure Black Spruce and Aspen Forests after Wildfire in Boreal Alberta, Canada
}

\author{
Stephanie A. Jean $(\mathbb{B}$, Bradley D. Pinno *(1) and Scott E. Nielsen ( \\ Department of Renewable Resources, University of Alberta, Edmonton, AB T6G 2E3, Canada; \\ sjean@ualberta.ca (S.A.J.); scottn@ualberta.ca (S.E.N.) \\ * Correspondence: bpinno@ualberta.ca
}

Received: 14 February 2020; Accepted: 12 March 2020; Published: 17 March 2020

check for updates

\begin{abstract}
Research Highlights: Black spruce (Picea mariana Mill.) and trembling aspen (Populus tremuloides Michx.) both regenerated vigorously after wildfire. However, pure semi-upland black spruce stands are at increasing risk of changing successional trajectories, due to greater aspen recruitment. Background and Objectives: Black spruce and aspen are found across the boreal forest with black spruce dominating lowlands and aspen being common in uplands. Both species are well adapted to wildfire with black spruce holding an aerial seedbank while aspen reproduce rapidly via root suckering. In the summer of 2016, the Horse River wildfire burned 589,617 hectares of northern Alberta's boreal forest. Methods: We assessed early regeneration dynamics of both pure aspen and pure black spruce forests. For black spruce, 12 plots were established in both bog and semi-upland habitats to assess seedling regeneration and seedbed availability. For aspen, 12 plots were established in each of the low, moderate, and high burn severities, as well as 5 unburned plots. Results: Post-fire black spruce regeneration densities did not differ between bog and semi-upland habitats, but were positively correlated with forb cover and charred organic matter seedbeds. Aspen regeneration within pure black sprue stands was substantial, particularly in semi-upland habitats, indicating a potential shift in successional trajectory. Fire severity did not significantly affect aspen regeneration in pure aspen stands, but regeneration density in all severity types was $>90,000$ stems ha $^{-1}$. Aspen regeneration densities were negatively related to post-fire forb and shrub cover, likely due to competition and cooler soil temperature.
\end{abstract}

Keywords: Populus tremuloides; Picea mariana; resiliency; forest regeneration; wildfire

\section{Introduction}

Boreal forest ecosystem dynamics are driven by natural disturbances such as fire, windthrow, insects, and disease outbreaks [1]. Fire is a major stand-renewing agent and plays an essential role in shaping boreal ecosystems by influencing species composition, age structure, productivity, and biodiversity [2]. Approximately $0.7 \%$ of the forested land in the boreal region burns annually [3], and this is expected to rise as fires become more frequent and harder to control due to a changing climate [4].

Black spruce (Picea mariana Mill.) hold aerial seed banks in the form of semi-serotinous cones, enabling them to respond quickly to disturbances. Mature trees can hold up to 6 years of closed cones allowing for a large potential seed source [5]. Although the majority of seed fall occurs in the first year post-fire, small amounts of seed rain can continue several years post fire, helping to ensure establishment during favorable years [6]. In the first $1-5$ years post fire, black spruce seedlings can be found in densities of up to 80,000 stems ha $^{-1}[7,8]$. 
Although black spruce is capable of providing thousands of seeds post-fire, appropriate seedbeds are needed for successful germination. Previous studies have found that best establishment usually occurs on mineral soil, thin organic soil, or sphagnum, because they are continually moist $[9,10]$. Fire often creates these favorable seedbeds by removing soil organic horizons, lichen and moss mats, other competing vegetation, and by blackening and warming the soil [11,12]. Higher intensity fires produce more of these favorable seedbeds and result in good black spruce establishment. However, heavy ash layers on the soil can inhibit germination immediately after fire because of decreased water permeability [13]. To our knowledge, most research on seedbed preference has taken place in northern circumpolar regions $[10,14,15]$, and it would be beneficial to also understand preferences in more southerly portions of the boreal, as well to better understand regeneration dynamics in different black spruce habitats.

In Alberta, there are two main types of black spruce forests, semi-upland and lowland. In semi-upland sites, mineral soil is typically found within $30 \mathrm{~cm}$ of the soil's surface and is imperfectly drained. Lowland sites are classified as treed bogs and have organic soils that are $\geq 80 \mathrm{~cm}$ thick, the soils are hydric and can have standing water. Semi-upland sites tend to be more productive in terms of tree growth, because the soils have better drainage and thinner organic layers. These two habitat types may provide different seedbeds for black spruce. Lowland sites will have greater organic matter seedbeds, while uplands should provide more mineral soil seedbeds.

Trembling aspen (Populus tremuloides Michx.) is well adapted to disturbances because it has a high capacity for vegetative reproduction [5]. Sprouts from lateral roots (root suckers) are the main form of regeneration after disturbance. However, stump sprouts can also be produced if the stem is removed. Root suckers are produced immediately after fire in numbers as high as 240,000 stems ha $^{-1}$ [16]. However, there is evidence of lower root suckering rates of aspen after high severity fires and under certain pre-fire stand conditions, such as unhealthy trees and low stand basal areas. Aspen can also colonize a site via windblown seeds capable of travelling long distances [8]. If preferable microsites, such as mineral soil, shallow organic matter, and mineral-organic matter mix, are present, aspen will regenerate successfully by seed, potentially occupying other habitat types $[17,18]$.

Generally, it is thought that forests within the boreal will regenerate to similar species composition and stem densities as before fire, known as the direct regeneration hypothesis [19]. However, deciduous trees may dominate a regenerating forest because of rapid asexual reproduction and long-distance transport of small wind-blown seeds $[8,20]$. These alternative successional trajectories can be driven by fire severity, pre-fire vegetation composition, site conditions, and fire effects on the reproductive potential of alternate dominant species [21]. Species interactions, such as herbivory and plant competition, can also alter the direction and timing of successional trajectories [14]. For example, in black spruce dominated stands, adjacent deciduous trees (e.g., trembling aspen) can populate an area via lateral root suckering $[8,22]$. High severity fires also consume organic material and expose mineral soil, leaving ideal seed beds for deciduous tree species, as well as other conifers, while scorching the aerial seed bank held by black spruce thereby reducing their viability [14,22]. In aspen-dominated stands, higher severity fires tend to cause more prolific asexual regeneration compared to low severity fires $[23,24]$. However, severe burns (forest floor is completely removed) have also been found to reduce aspen reproduction by consuming lateral roots [16], allowing other species to germinate on a mineral soil seedbed.

The goal of this study was to determine the effects of fire severity, habitat type, and stand characteristics on the regeneration of pure black spruce and pure aspen stands immediately after wildfire. We looked at black spruce and aspen stands separately, as the emphasis of research questions differed. For black spruce stands we sought to determine whether: (1) habitat type (i.e., bog or semi-upland) affected regeneration of black spruce stands; (2) stand characteristics (i.e., age, diameter at breast height (DBH), height, basal area, competition, and soil properties) affected regeneration in black spruce stands; and (3) seedbeds were differentially occupied by black spruce seedlings in different habitat types. For aspen forests, we asked whether: (1) fire severity affected the regeneration of aspen 
stands; and (2) stand characteristics (i.e., age, DBH, height, basal area, competition, soil properties) affected regeneration in aspen stands.

\section{Materials and Methods}

\subsection{Study Area}

This study took place after the Horse River fire (Figure 1), which burned an area of 589,617 hectares, making it Canada's fourth largest wildfire on record [25]. The Horse River Fire started on 1 May 2016, and was not classified as under control until 5 July 2016. Record high temperatures, low relative humidity, and strong winds caused the fire to undergo a dramatic increase in size shortly after ignition. At the time of the fire, the green-up of vegetation had not begun, resulting in dry fuel being available on the forest floor [26]. The Horse River fire occurred in the Central Mixedwood Natural Subregion of Alberta, characterized by aspen and aspen-white spruce forests on upland sites [27]. Semi-upland sites have imperfectly drained soils and are occupied by black spruce-dominated forests. Lowland areas consist of wet, poorly drained black spruce fens and bogs, which compose almost half the area of the subregion. Black spruce growing in lowland habitats is typically much smaller compared to those in semi-uplands. Upland soils are predominantly Gray Luvisols, semi-uplands are Gleysols, and lowland soils are Organic [28]. The subregion is characterized by short warm summers and long cold winters, with the average temperature of the warmest month being $15.9^{\circ} \mathrm{C}$ and average temperature of the coldest month being $-18.7^{\circ} \mathrm{C}$ (this is based on the Fort McMurray climate normal from Environment Canada). Mean annual precipitation is $469 \mathrm{~mm}$.

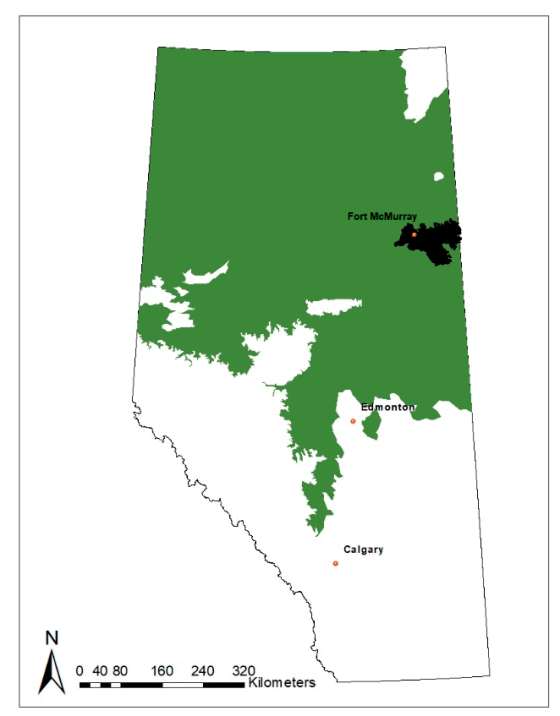

Figure 1. Map of field study area. Green area is the boreal forest within Alberta, Canada, while the black area is the Horse River fire, which burned an area of 589,617 ha in 2016.

\subsection{Field and Lab Methods}

After initial scouting, it was determined that while aspen stands burned across a gradient of different fire severities, black spruce stands only burned at high severities. This discrepancy in burn severities resulted in sites selected differently for each stand type. Black spruce-dominant stands ( $\geq 80 \%$ black spruce) were chosen by two general habitat types of black spruce in the area: semi-upland and bog. Aspen-dominant ( $\geq 80 \%$ aspen) stands were chosen across a gradient of fire severities (low, moderate, high, and unburned). Trees in both black spruce habitat types and across all aspen fire severities were approximately the same age ( $\sim 80$ years). Buffers between plots and forest edges were double the average tree height of a stand ( $60 \mathrm{~m}$ for aspen and $30 \mathrm{~m}$ for black spruce). 
In the summer of 2017, one year after the fire, 71 measurement plots were randomly placed in appropriate stands. Twelve plots were placed in each black spruce habitat type, and each habitat type had 3 unburned control plots. Twelve plots were placed in each aspen fire severity level, and there were 5 unburned control plots. At each site, circular plots with a radius of $5.67 \mathrm{~m}$ were established. Within each circular plot, North:South and East:West transects were also established. At each plot, tree regeneration, fire severity, and stand characteristics were measured and a soil sample taken. The Composite Burn Index (CBI) [29] was used to estimate burn severity. The CBI uses five strata levels in a community to determine the magnitude of fire effects. For this research, only the substrate and dominant/co-dominant tree strata were used, because pre-fire characteristics for other strata levels were unknown.

Tree and stand measurements included canopy height, stand age, and DBH from all trees with a $\mathrm{DBH}>7 \mathrm{~cm}$. These measurements were taken post-fire but represent pre-fire conditions. Canopy height was determined by measuring the heights of three average overstory trees. Tree cores were taken at breast height from three average-sized overstory trees to estimate stand age. Age was determined in the lab using CooRecorder software (Cybis Dendrochronology) after core preparation.

Soil grab samples, including litter, humus, and mineral soil, were collected from the four quadrants of each plot. If mineral soil was not present in the black spruce bog stands, two depths of organic soil were taken. These samples were then analyzed for $\mathrm{pH}$, electrical conductivity (EC), and texture with EC and pH measured in a soil to water ratio of 1:2 for mineral soils and 1:10 for organic soils using a sympHony ${ }^{\mathrm{TM}} \mathrm{pH}$ meter [30]. Mineral soil texture was determined using a Beckman Coulter LS 13320 laser particle size analyzer system (ISO method 13320). Decomposition state for organic soils was done by hand using the von Post scale of decomposition [28].

Tree regeneration, the main response variable, was measured using 20 subplots evenly spaced along the North:South and East:West transects within each plot. Subplot size depended on the stand type. Subplot size in aspen stands was $50 \mathrm{~cm} \times 50 \mathrm{~cm}$, as regeneration was very high. Subplots in black spruce stands were $100 \mathrm{~cm} \times 100 \mathrm{~cm}$, as regeneration rates were lower. In each subplot, seedlings or suckers were tallied and then averaged for the stand on a per hectare basis. Percent cover of vegetation functional groups (shrub, forb, grass, and bryophyte) was also estimated within each subplot. All measured aspen were root suckers (>50 cm tall one-year post-fire, green stem, large leaves) and this was confirmed through excavation for a minimum of one regenerating aspen stem per stand.

To determine preferred seedbeds for black spruce seedling establishment, we returned to 21 of the 24 black spruce sites in the summer of 2018. Three of the sites, all bog, were not revisited due to inaccessibility. Plot layout was similar to what was setup in 2017, with North:South and East:West transects inside of a $5.67 \mathrm{~m}$ plot. However, a smaller circular regeneration plot was also established at the plot center with a radius of $3.99 \mathrm{~m}$. This smaller regeneration plot was used to count the number of black spruce seedlings that were being established and note the seedbed type they were growing on. Sixty seedbed plots (5.67 $\mathrm{cm}$ radius) were placed along the transects, and within each seedbed plot, the dominant seedbed type was determined along with total vegetation cover. Seedbed types were classified as: mineral soil (concave and convex), unburned organic matter/hummocks (wet and dry), dead wood (within $5 \mathrm{~cm}$ ), charred organic matter, and other (rock, water, etc.). Concave mineral soil, charred organic matter, wet unburned organic matter, and deadwood seedbeds all had mesic conditions. Convex mineral soil and dry unburned organic matter had subxeric conditions. We did not examine seedbed preferences for aspen, because regeneration took place via root suckers.

\subsection{Statistical Analyses}

All data were analyzed using R software (R Core Team, 2018, Boston, MA, USA). Since aspen and black spruce regeneration variables were over-dispersed count data and could not be transformed, negative binomial models were used. First, to understand the differences between selected sites, within each stand type, several MANOVAs were performed (manova command in R 3.1.4). To determine the differences among pre-fire stand characteristics, basal area, height, and age were used as response 
variables and site selectors of fire severity and habitat type were used as explanatory variables. To determine the differences among post-fire stand characteristics, forb cover, grass cover, shrub cover, bryophyte cover, \% sand, \% silt, \% clay, $\mathrm{pH}$, and EC were all used as response variables and site selectors of fire severity and habitat type were used as explanatory variables.

Secondly, to determine the effects of the site variables of habitat type for black spruce stands and fire severity for aspen stands, negative binomial models were used ( $g l m . n b$ command in R 3.1.4). For the black spruce stands, two models were created. Both used habitat type as the only explanatory variable with one using black spruce regeneration and the other using aspen regeneration as the response variable. In the aspen stand, fire severity was the only explanatory variable used and the amount of aspen regeneration was the response variable. We then ran an analysis of deviance on each of the models (anova command in R 3.1.4). Thirdly, negative binomial models were used to determine what stand characteristics had an effect on regeneration rates. Models were chosen based on the lowest AIC score. Beta values were transformed to integer values, $e^{\beta}$, to more easily understand the magnitude of effects. Pseudo $\mathrm{R}^{2}$ values were calculated using the rms package (Version 5.1-1) [31].

Lastly, seedling preference values were derived for black spruce using the formula:

$$
\text { Preference }_{\text {seedbed }}=\frac{(\text { No. seedlings on seedbed } x) /(\text { Total no. of seedlings })}{(\text { No. of seedbed } x) /(\text { Total no. of seedbeds })}
$$

where a preference value of 1 indicates no preference for a seedbed, while greater values indicate preference and lower values indicate avoidance [17]. An ANOVA (anova command in R 3.1.4) was used compare seedbed preferences among the two habitat types. To meet the statistical assumptions of normality and homogeneity of variance, substrate preference for aspen seedlings was $\ln (x+1)$ transformed.

\section{Results}

\subsection{Regeneration in Black Spruce Stands}

Pre-fire basal area $(p=0.049)$ and height $(p=0.007)$ were greater in semi-upland areas compared to bog black spruce habitats (Table 1$)$, but there was no difference in stand age $(p=0.147)$. Post-fire forb cover $(p=0.021)$, shrub cover $(p=0.010)$, and EC $(p=0.042)$ were all higher in bog habitats. No other post-fire stand characteristics were different between habitat types $(p>0.05)$.

Table 1. Pre- and post-fire stand characteristics for each stand type sampled. Values are average (standard error), $n=12$ for each stand type. Pre-fire forests were all comprised of $\geq 80 \%$ either aspen or black spruce; other tree species were not included.

\begin{tabular}{|c|c|c|c|c|c|c|c|c|c|}
\hline Stand Type & Basal Area & Height & Forb & Shrub & Bryophyte & Clay & Sand & $\mathrm{pH}$ & $\begin{array}{l}\text { Electrical } \\
\text { Conductivity } \\
\text { (EC) }\end{array}$ \\
\hline & $\left(\mathrm{m}^{2} \mathrm{ha}^{-1}\right)$ & (m) & $(\%)$ & $(\%)$ & $(\%)$ & $(\%)$ & $(\%)$ & & $\left(\mu \mathrm{S} \mathrm{cm}^{-1}\right)$ \\
\hline Black spruce-Bog & $6.7(1.2)$ & $11.1(0.9)$ & $11(2)$ & $8(1.8)$ & $3(1.0)$ & - & - & $5.0(0.3)$ & $140(30.5)$ \\
\hline $\begin{array}{c}\text { Black } \\
\text { spruce-Semi-upland }\end{array}$ & $13.9(1.3)$ & $14.4(0.7)$ & $8(2)$ & $2(0.9)$ & $11(4.7)$ & $24.4(1.9)$ & $36.8(4.0)$ & $5.2(0.1)$ & 88 (11.9) \\
\hline $\begin{array}{c}\text { Black } \\
\text { spruce-Unburned } \\
\text { bog }\end{array}$ & $5.3(1.7)$ & $7.7(2.3)$ & $14(4)$ & $20(6.5)$ & $86(2.5)$ & - & - & $5.2(0.2)$ & $185(41.2)$ \\
\hline $\begin{array}{c}\text { Black } \\
\text { spruce-Unburned } \\
\text { semi-upland }\end{array}$ & $25.1(5.8)$ & $15.8(1.2)$ & $3(1)$ & $10(3.5)$ & $85(5.1)$ & $14.1(1.0)$ & $53.3(1.6)$ & $4.4(0.2)$ & $165(46.3)$ \\
\hline Aspen-Low & $32.7(3.5)$ & $22.7(1.1)$ & $224(3)$ & $9(2.0)$ & $2(0.8)$ & $31.5(2.5)$ & $16.0(3.2)$ & $6.0(0.1)$ & $124(14.2)$ \\
\hline Aspen-Moderate & $40.3(10.2)$ & $21.8(1.0)$ & $20(3)$ & $5(0.9)$ & 0 & $27.3(2.2)$ & $19.2(3.6)$ & $5.9(0.1)$ & $84(5.2)$ \\
\hline Aspen-High & $27.3(2.7)$ & $21.5(1.0)$ & $26(3)$ & $6(0.9)$ & $1(0.3)$ & $26.5(2.2)$ & $23.0(3.6)$ & $5.9(0.1)$ & $106(5.2)$ \\
\hline Aspen-Unburned & $22.9(4.5)$ & $21.9(1.1)$ & $20(3)$ & $10(4.2)$ & $1(1.3)$ & $18.1(6.1)$ & $56.4(10.8)$ & $5.6(0.3)$ & $84(9.7)$ \\
\hline
\end{tabular}


Across all burned black spruce stands, regeneration was primarily comprised of black spruce $(60 \%)$ and aspen (32\%). However, balsam poplar (Populus balsamifera L.) and jack pine (Pinus banksiana Lamb.) were also present in small numbers ( $7 \%$ and $1 \%)$. Black spruce regeneration was highly variable, ranging from 0 to 43,000 stems ha ${ }^{-1}$ in bogs and 0 to 39,500 stems ha $^{-1}$ in semi-upland forests. Aspen regeneration was also highly variable, ranging from 0 to 17,000 stems ha $^{-1}$ in bogs and from 0 to 36,000 stems ha $^{-1}$ in semi-uplands. There was no significant difference in black spruce regeneration across the two habitat types $\left(\overline{x_{\text {bog }}}=13,375 ; \overline{x_{\text {semi-upland }}}=10,583\right.$ stems ha $\left.^{-1} ; p=0.698\right)$, however semi-upland habitats allowed for significantly greater aspen regeneration via root suckers $\left(\overline{x_{\text {bog }}}=8000 ; \overline{x_{\text {semi-upland }}}=43,667\right.$ stems ha $^{-1} ; p=0.011$; Figure 2$)$. In the unburned controls, black spruce regeneration averaged 3667 stems ha $^{-1}$ and was concentrated in the bog habitats.

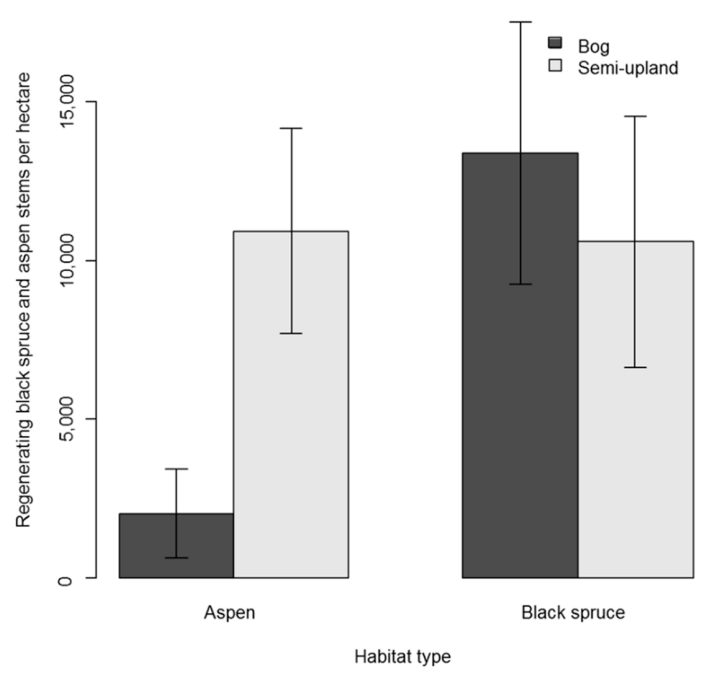

Figure 2. Black spruce and aspen regeneration (stems per hectare) on different black spruce habitat types. Values are mean and standard error.

Black spruce regeneration was positively correlated with forb cover $(\beta=1.448, p<0.001$, pseudo $\left.\mathrm{R}^{2}=0.396\right)$. For each $10 \%$ increase in forb cover, there were approximately 8500 more regenerating black spruce seedlings ha ${ }^{-1}$ (Figure 3). Aspen regeneration was greater in semi-upland habitats, but was not affected by stand and site characteristics, including basal area, tree height, tree age, competition levels, or soil properties.

Seedbed type had a significant effect on the establishment of black spruce seedlings, with habitat types having significantly different availabilities of seedbeds $(p=0.009)$. Semi-upland habitats had significantly more dead wood seedbeds $(p<0.001)$, while bog habitats had significantly more dry unburned organic matter $(p=0.014)$.

In terms of seedbed availability, dry unburned organic matter was the most common at $58 \%$, followed by charred organic matter at $22 \%$ and dead wood at $11 \%$, convex mineral soil, wet unburned organic matter, and other seedbeds comprised of $<10 \%$ of the available seedbeds (Figure $4 \mathrm{~A}$ ). Of the 552 seedlings observed in bog habitats, $40 \%$ were being established on dry unburned organic matter, $29 \%$ on charred organic matter, $27 \%$ on wet unburned organic matter, $3 \%$ on dead wood, and $<1 \%$ on convex mineral soil (Figure 4A). 


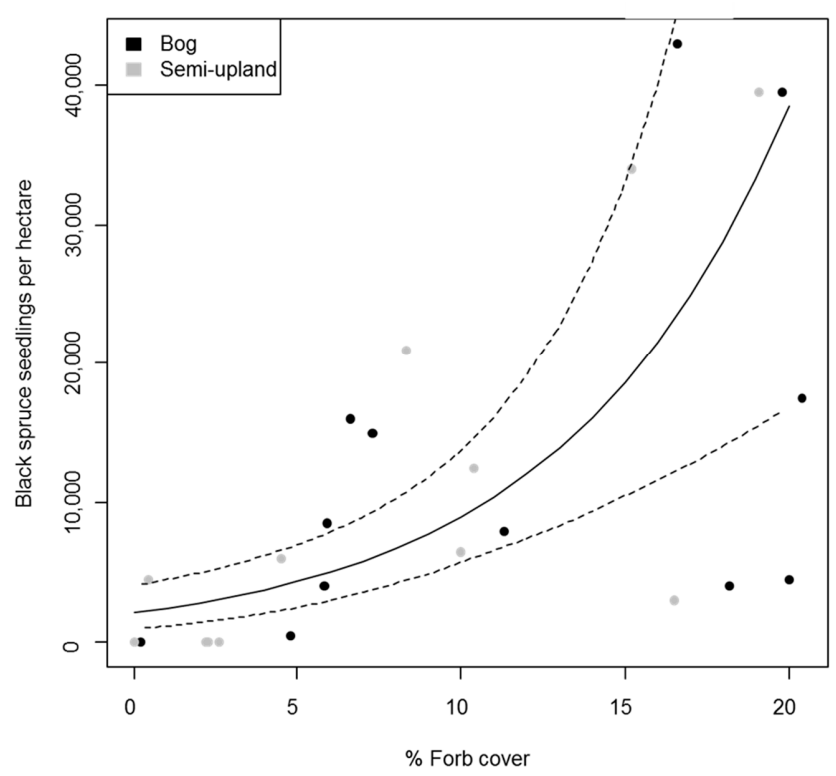

Figure 3. Observed black spruce regeneration density over a range of forb cover (\%) with a fitted negative binomial curve (solid line) and 95\% confidence bands (dotted lines).

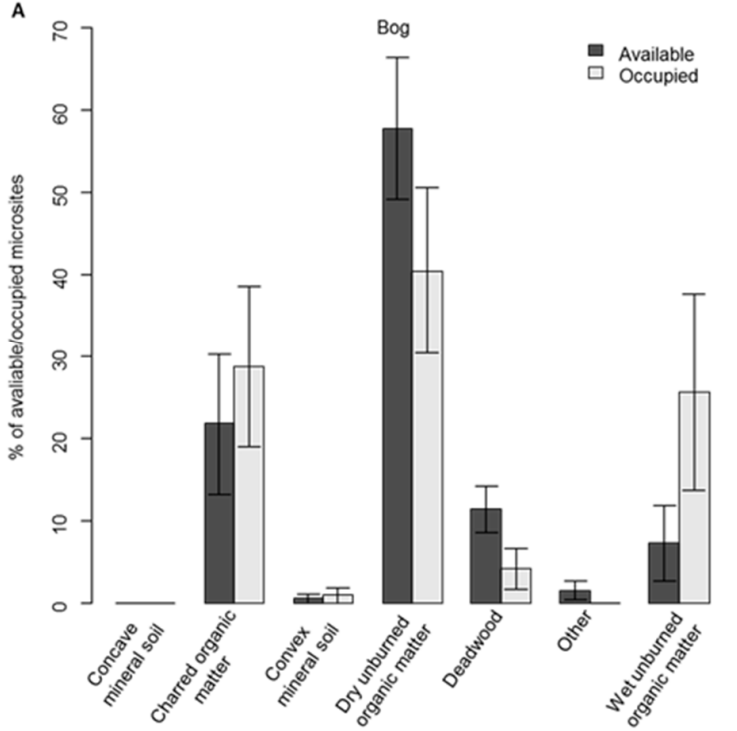

B

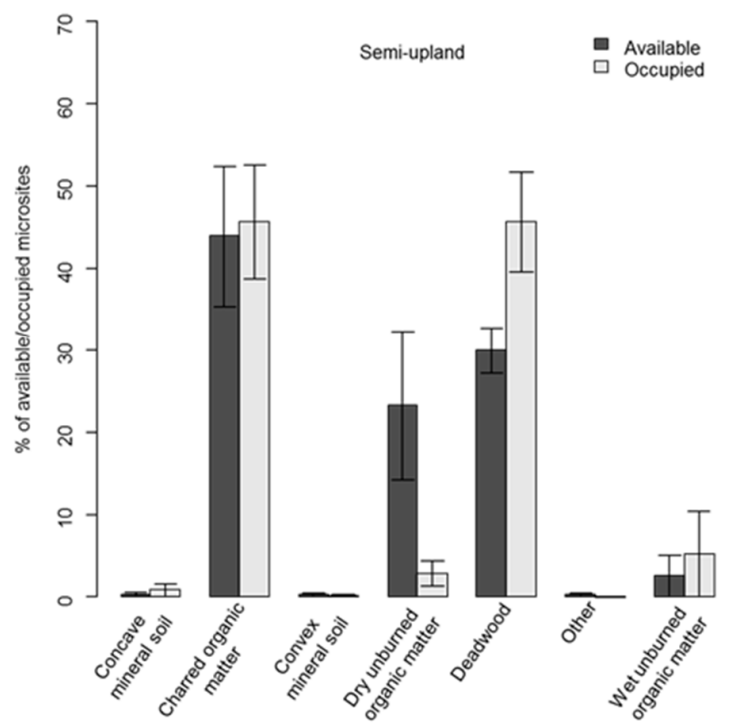

Figure 4. (A) Percent of black spruce seedlings occupying various seedbed types and the percent frequency of each substrate type in bog habitat types. (B) Percent of black spruce seedlings occupying various seedbed types and the percent frequency of each substrate type in semi-upland habitat types.

Charred organic was the most common seedbed available in semi-upland habitats at $44 \%$, followed by dead wood at $30 \%$ and dry unburned organic matter at $23 \%$, convex mineral soil, concave mineral soil, wet unburned organic matter, and other seedbeds made up $<5 \%$ of available seedbeds (Figure $4 \mathrm{~B}$ ). Of the 1457 seedlings observed, $48 \%$ established on dead wood, $45 \%$ on charred organic matter, $4 \%$ on wet unburned organic matter, $2 \%$ on dry unburned organic matter, and $<1 \%$ on convex and concave mineral soil combined (Figure 4B). Black spruce seedlings tended to prefer charred organic matter as a seedbed in both habitats $(p=0.021)$. In bogs, wet unburned organic matter was also a preferred seedbed, while dry unburned organic matter was preferred only slightly. In semi-uplands, dead wood and wet unburned organic matter were other preferred seedbeds. Preference values for all other substrates were low. 


\subsection{Regeneration in Aspen Stands}

There were no significant differences in aspen pre-fire stand characteristics ( $p=0.671$; Table 1$)$. In pure aspen stands, regeneration was dominated by aspen ( $99.5 \%$ of all regenerating stems). However, balsam poplar $(0.4 \%)$ and white spruce $(0.1 \%)$ [Picea glauca (Moensch) Voss] were also present in small numbers. Aspen regeneration ranged from 14,000 to 294,000 stems ha ${ }^{-1}$. In general, moderate severity fires had the greatest amount of regeneration, followed by high and low severity $\left(\overline{x_{\text {low }}}=93,384\right.$, $\overline{x_{\text {mod }}}=122,909, \overline{x_{\text {high }}}=104,000$ stems ha $^{-1}$; Figure 5) with differences being marginally significant $(p=0.082)$. Unburned stands had little aspen regeneration, with only 5 regenerating aspen stems found across all 5 unburned stands.

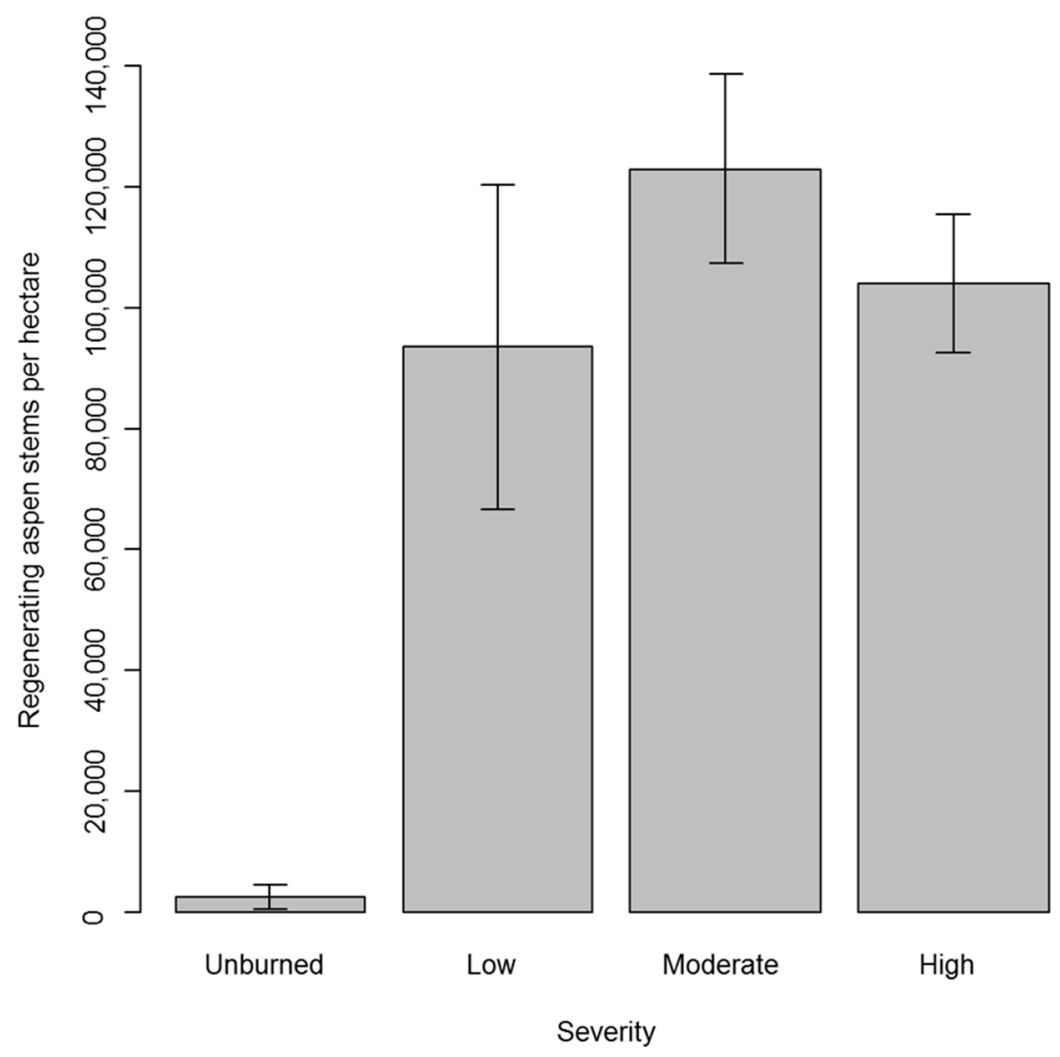

Figure 5. Aspen regeneration (stems per hectare) across the three fire severities (low, moderate, and high) and in unburned stands. Values are mean and standard error.

For burned stands, forb and shrub cover negatively affected regeneration of aspen ( $\beta_{\text {forb }}=-0.017$, $\mathrm{p}_{\text {forb }}=0.036, \beta_{\text {shrub }}=-0.076, \mathrm{p}_{\text {shrub }}<0.001$, pseudo $\left.\mathrm{R}^{2}=0.475\right)$. Specifically, a $10 \%$ increase in either forb or shrub cover decreased aspen regeneration by approximately 20,000 stems/ha (Figure 6). 


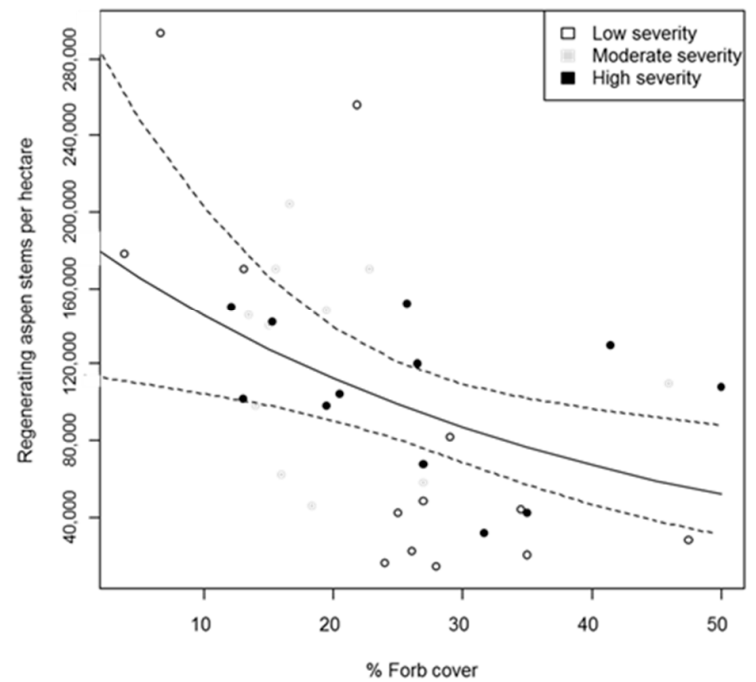

B

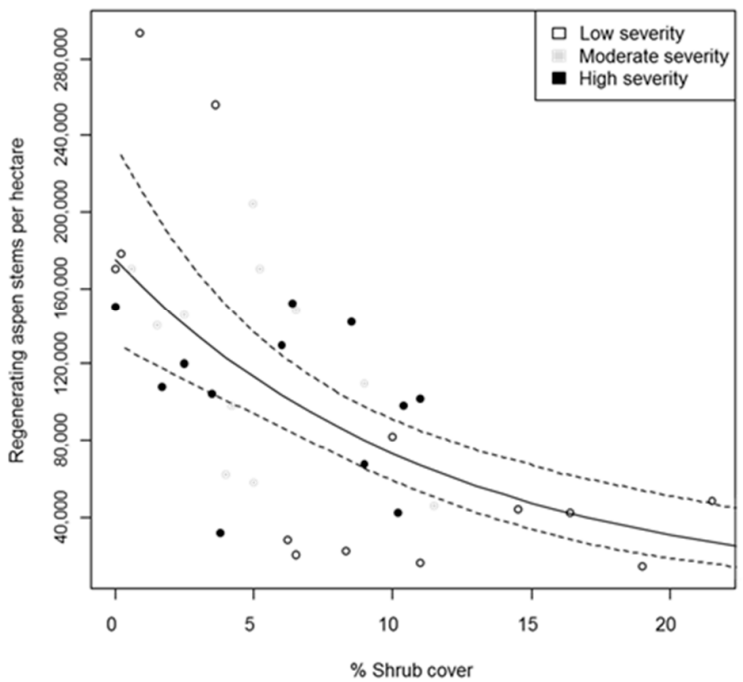

Figure 6. (A) Observed amount of aspen regeneration over a range of forb cover (\%) with a fitted negative binomial GLM curve (solid line) and 95\% confidence bands (dotted lines). (B) Observed amount of aspen regeneration over a range of shrub cover (\%) with a fitted negative binomial curve (solid line) and 95\% confidence bands (dotted lines). Regeneration reported in stems per hectare.

\section{Discussion}

Black spruce regeneration densities averaged 11,979 stems ha ${ }^{-1}$ and were slightly lower than expected. Past studies have found that black spruce typically regenerate in numbers of about 40,000 stems ha ${ }^{-1}$ and as high as 80,000 stems ha $^{-1}$ [7,8,32]. Other studies, however, took regeneration measurements at least 5 years post-fire. Black spruce has been found to take 5 to 10 years to reach maximum seedling establishment [33], therefore, black spruce establishment could further increase in our stands within the next few years. Although initial black spruce regeneration densities were lower than expected, these forests would still be considered adequately re-stocked [34].

Pre-fire stand basal area and height were both greater in semi-uplands. Black spruce growing on wetter bog sites have been shown to have reduced growth rates compared to trees growing in more upland sites $[35,36]$, mainly due to low oxygen availability to the tree roots in water-saturated soils [37,38]. Greater tree productivity is linked to greater seed production [39], so semi-upland forests would likely have seen greater amounts of seed rain post-fire. However, semi-uplands did not see greater amounts of black spruce regeneration, and in fact, on average they saw slightly lower amounts of regeneration. This discrepancy can likely be explained by lower seedbed availability.

Across both habitat types, black spruce regeneration increased with forb cover, suggesting preferable seedbed availability for both forbs and black spruce. Black spruce tends to establish on mineral soil, thin organic soil, or moss seedbeds $[9,10,15]$. It has been thought that these seedbeds are preferred because of their ability to provide constant moisture. We found similar results with charred organic matter, which would be comparable to a thin organic soil, as a preferred seedbed at both habitat types. Moss (wet unburned organic matter) was also a preferred seedbed. Our results, however, did not show a preference for mineral soil. This could be explained by a lack of mineral soil availability. Previous studies have made no mention of deadwood as a preferred seedbed, however, deadwood and the soil around it was a preferred seedbed on semi-upland habitats in our study. Moss seedbeds are thought to be optimal because of their high moisture retention and low temperature $[15,40]$. Bog habitats had more moss seedbeds available compared to semi-uplands, which may explain why bogs saw more black spruce regeneration on average. Our results are an important first step in understanding seedbed preferences for black spruce in Alberta's boreal forest, allowing for better forest management and aiding in black spruce reforestation. 
The large amount of aspen regeneration in previously pure black spruce stands was surprising. In semi-uplands, aspen regeneration averaged 10,917 stems ha $^{-1}$, nearly matching the regeneration of black spruce. All measured aspen were root suckers, therefore, proximity to aspen stands was likely the main factor affecting local patterns in aspen regeneration. Aspen regeneration in black spruce stands was not affected by any post-fire stand characteristics, likely because root suckers are sustained by parent tree root systems for some time after fire [41], so the amount of regeneration would be directly related to aspen root densities.

These high regeneration densities of aspen in black spruce stands could indicate a change in forest successional trajectory. Successional processes in black spruce have traditionally been viewed as a simple cycle of self-replacement after fire. However, with changing climate and fire regimes, it has been found that black spruce forests may be more susceptible to change than originally thought [14]. A change in successional pathways has already been seen in Alaska's boreal forests [8], with sites previously dominated by black spruce now seeing domination by deciduous trees in early successional stages. This study seems to show evidence of this occurring in Alberta's boreal forests as well, especially in semi-upland habitats.

Increases in deciduous tree species cover will also contribute to changes in the fire regime for stands previously dominated by black spruce. Black spruce have a large amount of fine twigs and needles, high resin content, low moisture content, and large quantities of fine ground fuels that are connected to the canopy, creating a highly flammable environment [14]. Deciduous tree species are much less flammable due to higher moisture content and reduced amounts of fine fuels [42]. Our findings correspond with this, as we found that pure aspen stands burned at differing severity levels, while black spruce stands burned only at high severities. For forest managers, understanding how black spruce forests can shift in successional trajectories can help with predicting how changes in fire regimes may shape future forest cover.

Aspen regeneration across different burn severity levels was not different. However, an average regeneration rate of 105,944 stems $\mathrm{ha}^{-1}$ demonstrates that these post-fire forests will easily be fully stocked aspen forests [34]. This large amount of regenerating aspen is similar to results found in some studies in western Canada [16], but much higher compared to other studies in the western United States [43]. Low severity burns saw the least amount of regeneration on average, likely because there was not complete overstory mortality and sucker production was not initiated in all trees. Since there was not complete overstory mortality, and there were still many suckers produced, it is likely that these forests will become uneven-aged stands. This could change our perspective on forest management, as it is generally assumed in the area that all stands are even-aged after fire.

Increasing amounts of forb and shrub cover were found to inhibit aspen sucker regeneration. These findings support other studies showing that vegetative competition can significantly reduce aspen suckering through competition for resources and cooling of the soil, which can inhibit sucker initiation [44,45]. Shrub cover had a greater effect on aspen suckering compared to forb cover, although forb cover was typically much greater than shrub cover (Table 1). Shrubs are larger and are more capable of competing for resources than forbs, they also would shade the soil much more than forbs, cooling the soil and blocking light from a shade-intolerant species. This information could be used by forest managers in areas where aspen regeneration is low, with understory vegetation removal being considered to facilitate more root suckering.

\section{Conclusions}

In conclusion, both black spruce and trembling aspen regeneration post-wildfire was substantial enough for both stand types to be considered adequately restocked. Regeneration of black spruce was positively correlated with forb cover, likely due to higher availability of preferable microsites for seed germination. Conversely, aspen regeneration was negatively correlated with forb and shrub cover, likely due to competition. High regeneration of trembling aspen was observed in semi-upland black spruce stands, which could indicate a change in successional trajectory. A changing climate and 
changing fire regimes could allow deciduous forests to replace these once pure black spruce stands. In turn, higher amounts of deciduous forests would also alter fire regimes, due to characteristics that make them less flammable than conifers. Understanding these shifts in successional trajectories and fire regimes could help predict changes in future forest cover and allow for better management.

Author Contributions: Conceptualization, S.A.J., B.D.P. and S.E.N.; methodology, S.A.J. and B.D.P.; field work, S.A.J.; data analysis, S.A.J.; writing—original draft preparation, S.A.J.; writing—review and editing, S.A.J., B.D.P. and S.E.N.; supervision, B.D.P. and S.E.N.; project administration, B.D.P. and S.E.N.; funding acquisition, B.D.P. All authors have read and agreed to the published version of the manuscript.

Funding: This research was funded by Natural Resources Canada's Energy Innovation Program. The APC was funded by the University of Alberta.

Acknowledgments: We thank Ryan Lalonde and Jim Weber for their help with field and lab work and Kaitlyn Trepanier for preparing Figure 1.

Conflicts of Interest: The authors declare no conflict of interest. The funders had no role in the design of the study; in the collection, analyses, or interpretation of data; in the writing of the manuscript, or in the decision to publish the results.

\section{References}

1. Brandt, J.P.; Flannigan, M.D.; Maynard, D.G.; Thompson, I.D.; Volney, W.J.A. An introduction to Canada's boreal zone: Ecosystem processes, health, sustainability, and environmental issues. Environ. Rev. 2013, 21, 207-226. [CrossRef]

2. Weber, M.G.; Flannigan, M.D. Canadian boreal forest ecosystem structure and function in a changing climate: Impacts on fire regimes. Environ. Rev. 1997, 5, 145-166. [CrossRef]

3. Stocks, B.J.; Mason, J.A.; Todd, J.B.; Bosch, E.M.; Wotton, B.M.; Amiro, B.D.; Flannigan, M.D.; Hirsch, K.G.; Logan, K.A.; Martell, D.L.; et al. Large forest fires in Canada, 1959-1997. J. Geophys. Res. 2002, 107, 1-12. [CrossRef]

4. De Groot, W.J.; Flannigan, M.D.; Cantin, A.S. Climate change impacts on future boreal fire regimes. For. Ecol. Manag. 2012, 294, 35-44. [CrossRef]

5. Greene, D.F.; Zasada, J.C.; Sirois, L.; Kneeshaw, D.; Morin, H.; Charron, I.; Simard, M.J. A review of the regeneration dynamics of North American boreal forest tree species. Can. J. For. Res. 1999, 29, 824-839. [CrossRef]

6. Thomas, P.A.; Wein, R.W. Delayed emergence of four conifer species on postfire seedbeds in eastern Canada. Can. J. For. Res. 1985, 15, 727-729. [CrossRef]

7. Foote, J.M. Classification, Description, and Dynamics of Plant Communities after Fire in the Taiga of Interior Alaska; Research Paper PNW-RP-307; Department of Agriculture, Forest Service, Pacific Northwest Forest and Range Experiment Station: Portland, OR, USA, 1983.

8. Johnstone, J.F.; Chapin, F.S., III. Fire interval effects on successional trajectory in boreal forests of northwest Canada. Ecosystems 2006, 9, 268-277. [CrossRef]

9. Horton, K.W.; Lees, J.C. Black Spruce in the Foothills of Alberta; Note 110; Canadian Department of Forestry, Forest Research Branch: Ottawa, ON, Canada, 1961.

10. Lloyd, A.H.; Fastie, C.L.; Eisen, H. Fire and substrate interact to control the northern range limit of black spruce (Picea mariana) in Alaska. Can. J. For. Res. 2007, 37, 2480-2493. [CrossRef]

11. Black, R.A.; Bliss, L.C. Reproductive ecology of Picea mariana (Mill.) BSP, at tree line near Inuvik, Northwest Territories, Canada. Ecol. Monogr. 1980, 50, 331-354. [CrossRef]

12. Auclair, A.N.D. The role of fire in lichen-dominated tundra and forest-tundra. In The Role of Fire in Northern Circumpolar Ecosystems; Wein, R.W., MacLean, D.A., Eds.; John Wiley \& Sons: New York, NY, USA, 1983; pp. 235-256.

13. Kemball, K.J.; Wang, G.G.; Westwood, A.R. Are mineral soils exposed by severe wildfire better seedbeds for conifer regeneration? Can. J. For. Res. 2006, 36, 1943-1950. [CrossRef]

14. Johnstone, J.F.; Hollingsworth, T.N.; Chapin, F.S., III. A Key for Predicting Postfire Successional Trajectories in Black Spruce Stands of Interior Alaska; General Technical Report PNW-GTR-767; United States Department of Agriculture, Forest Service, Pacific Northwest Research Station: Portland, OR, USA, 2008. 
15. Mallik, A.; Kayes, I. Lichen mated seedbeds inhibit while moss dominated seedbeds facilitate black spruce (Picea mariana) seedling regeneration in post-fire boreal forest. For. Ecol. Manag. 2018, 427, 260-274. [CrossRef]

16. Wang, G.G. Early regeneration and growth dynamics of Populus tremuloides suckers in relation to fire severity. Can. J. For. Res. 2003, 33, 1998-2006. [CrossRef]

17. Landhäusser, S.M.; Deshaies, D.; Lieffers, V.J. Disturbance facilitates rapid range expansion of aspen into higher elevations of the Rocky Mountains under a warming climate. J. Biogeogr. 2010, 37, 68-76. [CrossRef]

18. Landhäusser, S.M.; Pinno, B.D.; Mock, K.E. Tamm Review: Seedling-based ecology, management, and restoration in aspen (Populus tremuloides). For. Ecol. Manag. 2019, 432, 231-245. [CrossRef]

19. Yih, K.; Boucher, D.H.; Vandermeer, J.H.; Zamora, N. Recovery of the rain forest of Southeastern Nicaragua after destruction by Hurricane Joan. Biotropica 1991, 23, 106-113. [CrossRef]

20. Bergeron, Y.; Chen, H.Y.H.; Kenkel, N.C.; Leduc, A.L.; Macdonald, S.E. Boreal mixedwood stand dynamics: Ecological processes underlying multiple pathways. For. Chron. 2014, 90, 202-213. [CrossRef]

21. Peters, V.S.; Macdonald, S.E.; Dale, M.R.T. The interaction between masting and fire is key to white spruce regeneration. Ecology 2005, 86, 1744-1750. [CrossRef]

22. Johnstone, J.F.; Hollingsworth, T.N.; Chapin, F.S., III; Mack, M.C. Changes in fire regime break the legacy lock on successional trajectories in Alaskan boreal forests. Glob. Chang. Biol. 2009, 16, 1-15. [CrossRef]

23. Wan, H.Y.; Olson, A.C.; Muncey, K.D.; Clair, S.B.S. Legacy effects of fire size and severity on forest regeneration, recruitment, and wildlife activity in aspen forests. For. Ecol. Manag. 2014, 329, 59-68. [CrossRef]

24. Shinneman, D.J.; Krasnow, K.D.; McIlroy, S.K. The Role of Fire in Aspen Ecology and Restoration; WAA Briefs\# 3; Utah State University: Logan, UT, USA, 2015.

25. Natural Resources Canada. The State of Canada's Forests-Annual Report 2017; Government of Canada: Ottawa, ON, Canada, 2017.

26. Kochtubajda, B.; Brimelow, J.; Flannigan, M.; Morrow, B.; Greenhough, M.D. The extreme 2016 wildfire in Fort McMurray, Alberta, Canada. Bull. Am. Meteorol. Soc. 2017, 7, 176-177.

27. Downing, D.J.; Pettapiece, W.W. Natural Regions and Subregions of Alberta; No. T/852; Government of Alberta Publish: Edmonton, AB, Canada, 2006; 264p.

28. Soil Classification Working Group. The Canadian System of Soil Classification, 3rd ed.; Agriculture and Agr-Food Canada, Publication 1646; NRC Research Press: Ottawa, ON, Canada, 1998; 187p.

29. Key, C.H.; Benson, N.C. Landscape assessment: Ground measure of severity, the composite burn index; and remote sensing of severity, the Normalized Burn Ratio. In FIREMON: Fire Effects Monitoring and Inventory System; Lutes, D.C., Keane, R.E., Caratti, J.F., Key, C.H., Benson, N.C., Sutherland, S., Gangi, L.J., Eds.; RMRS-GTR-164-CD; USDA Forest Service, Rocky Mountain Research Station: Ogden, UT, USA, 2006; pp. 1-51.

30. Hendershot, W.H.; Lalande, H.; Duquette, M. Soil reaction and exchangeable acidity. In Soil Sampling and Methods of Analysis, 2nd ed.; Carter, M.R., Gregorich, E.G., Eds.; CRC Press: Boca Raton, FL, USA, 2007.

31. Harrell, F.E. Rms: Regression Modelling Strategies; R Package Version 5.1-1; Springer: Heidelberg, Germany, 2017.

32. Chrosciewicz, Z. Burning for black spruce regeneration on a lowland cutover site in southeastern Manitoba. Can. J. For. Res. 1976, 6, 179-186. [CrossRef]

33. Johnstone, J.F.; Chapin, F.S., III; Foote, J.; Kemmett, S.; Price, K.; Viereck, L. Decadal observations of tree regeneration following fire in boreal forests. Can. J. For. Res. 2004, 34, 267-273. [CrossRef]

34. Greene, D.F.; Kneeshaw, D.D.; Messier, C.; Lieffers, V.; Cormier, D.; Doucet, R.; Coats, K.D.; Groot, A.; Grover, G.; Calogeropoulos, C. Modelling silvicultural alternatives for conifer regeneration in boreal mixedwood stands (aspen/white spruce/balsam fir). For. Chron. 2002, 78, 281-295. [CrossRef]

35. Lacey, M.E.; Dech, J.P. Comparison of black spruce (Picea mariana) radial growth reduction in different soil moisture regimes during a spruce budworm (Choristoneura fumiferana) outbreak. Can. J. For. Res. 2012, 42, 1410-1419. [CrossRef]

36. Bubier, J.L. Patterns of Picea mariana (black spruce) growth and raised bog development in Victory Basin, Vermont. Bull. Torrey Bot. Club 1991, 118, 399-411. [CrossRef]

37. Crawford, R.M.M. Root survival in flooded soils. In Mires: Swamp, Bog, Fen, and Moor; Gore, A.J.P., Ed.; Elsevier: Amsterdam, The Netherlands, 1983; Volume 4A. 
38. Lieffers, V.J.; Rothwell, R.L. Rooting of peatland black spruce and tamarack in relation to depth of water table. Can. J. Bot. 1987, 65, 817-821. [CrossRef]

39. Viglas, J.N.; Brown, C.D.; Johnstone, J.F. Age and size effects on seed productivity of northern black spruce. Can. J. For. Res. 2013, 43, 534-543. [CrossRef]

40. Wheeler, J.A.; Hermanutz, L.; Marino, P.M. Feathermoss seedbeds facilitate black spruce seedling recruitment in the forest-tundra ecotone (Labrador, Canada). Oikos 2011, 120, 1236-1271. [CrossRef]

41. Lambers, H.; Atkin, O.K.; Millenaar, F.F. Respiratory patterns in roots in relation to their functioning. In Plant Roots, the Hidden Half, 3rd ed.; Waisel, Y., Eshel, A., Kafkafi, U., Eds.; Marcel Dekker: New York, NY, USA, 2002; pp. 521-552.

42. Hély, C.; Bergeron, Y.; Flannigan, M.D. Effects of stand composition on fire hazard in mixed-wood Canadian boreal forest. J. Veg. Sci. 2000, 11, 813-824. [CrossRef]

43. Brown, J.K.; Bebyle, N.V. Fire damage, mortality, and suckering in aspen. Can. J. For. Res. 1987, 17, 1100-1109. [CrossRef]

44. Hogg, E.H.; Lieffers, V.J. The impact of Calamagrostis canadensis on soil thermal regimes aftere logging in northern Alberta. Can. J. For. Res. 1991, 21, 387-394. [CrossRef]

45. Landhäusser, S.M.; Lieffers, V.J. Growth of Populus tremuloides in association with Calamagrostis canadensis. Can. J. For. Res. 1998, 28, 396-401. [CrossRef]

(C) 2020 by the authors. Licensee MDPI, Basel, Switzerland. This article is an open access article distributed under the terms and conditions of the Creative Commons Attribution (CC BY) license (http://creativecommons.org/licenses/by/4.0/). 